\title{
Heikki Aittokoski, Onnellisten saari. Matka täydelliseen yhteiskuntaan
}

Helsinki: Sanoma, 2020, 358 s.

Heikki Aittokosken trilogian kolmas kirja kantaa nimeä Onnellisten saari. Sarjan ensimmäinen osa Narrien Laiva (2013) käsittelee epäonnistuneita yhteiskuntia ja toinen osa Kuoleman tanssi (2016) nationalismin nousua Euroopassa. Narrien laiva viittaa nimellään vuonna 1494 julkaistuun Sebastian Brantin teokseen Das Narren Schyff, joka runomuodossa moittii yltäkylläistä elämää. Kirjassa kyytiä saavat epäonnistuneet valtiot kuten Päiväntasaajan Guinea, Somalia ja Nicaragua. Tuoreimmassa teoksessaan Aittokoski matkaa vastaavasti sellaisissa maissa, joita tavalla tai toisella voidaan pitää onnellisina, kuten Bhutan, Botswana, Costa Rica, Yhdysvallat, Tanska ja luonnollisesti myös Suomi. Suomi onkin valittu jo useita kertoja maailman onnellisimmaksi maaksi (Yhdistyneet kansakunnat 2020).

Kaikki Pohjoismaat mahtuvat vertailussa seitsemän parhaan joukkoon, kun taas viimeiseksi sijoittuu Afganistan. Raportti huomioi muun muassa bruttokansantuotteen ja korruption määrän sekä ihmisten sosiaaliset tukiverkostot, terveydentilan, anteliaisuuden ja vapauden tehdä valintoja.

Heikki Aittokosken kirja pureutuu ei vähempään kuin hyvän yhteiskunnan pohdintaan. Lähtökohtana hänellä on vuonna 1516 ilmestynyt Thomas Moren Utopia (More 1971), joka hahmottelee paikkaa, jossa vallitsee vapaus. Se on kuvaus ihanneyhteiskunnasta ja Moren vastalause aikansa vallitseville yhteiskunnallisille oloille. Valtion kansalaisina utopialaiset pitävät yllä yhteisomistusta, ja vanhimpien kunnioitus on hyve. Heillä ei ole tarvetta varastaa, koska omasta mielestään heillä on kaikkea riittävästi. Niinpä lainsäädäntö on yksinkertainen.

More tapasi useita kertoja Erasmus Rotterdamilaisen (2010), jonka kirjasta Tyhmyyden ylistys (1511) More luultavimmin sai vaikutteita omaansa. Moren lisäksi Aittokoski viittaa muihin, utopioista kirjoittaneisiin, kuten August Strindbergiin (1912) ja tämän novelliin De lycksaliges $\ddot{o}$ (ilmestyi vuonna 1883). Mielestäni Aittokoski olisi voinut käsitellä myös suomalaisten siirtolaisten eri puolille maailmaa perustamia ihanneyhteiskuntia, jotka tosin olivat pieniä eivätkä yleensä menestyneet kovinkaan hyvin.

Aittokoski käsittelee onnellisuuden teemaa maakohtaisesti, ja valitut valtiot edustavat tavalla tai toisella toimivia yhteiskuntia. Aittokosken kerrontatyyli on journalistinen, tiiviissä kappaleissa pääosassa ovat yksittäiset ihmiset, joiden kanssa ja kautta Aittokoski pohtii hyvän ja onnellisen yhteiskunnan olemusta. Kirjan ensimmäinen maa on Bhutan, joka todella on virallisesti asettanut onnellisuuden kansalliseksi tavoitteeksi ja mittaa sitä (Gross National Happiness, GNH) (GNH Centre 2020). Bhutan on maatalousvaltainen ja eristäytynyt valtio, jonka tuloista suuri osa tulee vesivoiman myynnistä. Bhutan on esimerkki valtiosta, jossa onnellisuus ei ole suoraan sidoksissa taloudelliseen hyvinvointiin. Bhutan ei ole demokratia länsimaisessa merkityksessä; lohikäärmekuninkaan auktoriteettia ei kyseenalaisteta.

Teoksen kaksi muuta ei-läntistä demokratiaa ovat Botswana ja Costa Rica. Botswana näyttää Aittokosken mukaan painivan omassa sarjassaan. Se on lähes yhtä kehittynyt kuin suuri naapurinsa Etelä-Afrikka, mutta asuinpaikkana se on ehdottomasti Etelä-Afrikkaa turvallisempi. Useista Afrikan maista poiketen Botswanaa eivät myöskään riivaa etniset konfliktit. Botswana 
luonnonrikkautena ovat timantit, joita maaperästä on kaivettu yli 50 vuotta. Timanttitalouden rakenteellisena ongelmana on se, etteivät kaivokset luo kovin paljon työpaikkoja. Costa Rica taas tunnetaan valtiona, joka on luopunut armeijasta vuonna 1948. Costa Rica sijoittui YK:n onnellisuusvertailussa 12. sijalle (Yhdistyneet kansakunnat 2020). Muista kärkeen yltäneistä maista poiketen Costa Rica ei ole rikas teollisuusmaa. Aittokosken mukaan Costa Rican näkymättömyys (mediassa) on merkki siitä, että on tehty jotain oikein.

Kirjan muut esimerkit taas edustavat bruttokansantuotteella mitattuna rikkaita valtioita. Yhdysvaltojen perustuslaki vuodelta 1776 mainitsee onnellisuuden tavoittelun: "... kaikki ihmiset on luotu samanarvoisiksi, että Luoja on suonut heille tiettyjä luovuttamattomia oikeuksia, joita ovat Elämä, Vapaus ja Onnellisuuden tavoittelu." Vaikka hyvän elämän turvaaminen voidaan nykyisin katsoa demokraattisesti valitun hallituksen perustehtäväksi, 1770-luvulla nämä ideat olivat vallankumouksellisia ja niitä luettiin ahnaasti myös merten takana (s. 69). Yhdysvallat näyttäytyy siis valtiona, joka on ollut edelläkävijä onnellisuuden tavoittelussa, mutta ei ole onnistunut jakamaan sitä kaikille kansalaisille. Oikeudet eivät koskeneet suurta osaa kansasta, kuten orjia. Yhdysvallat näyttäytyy kapitalismin johtavana maana, jossa eriarvoisuus on räikeää ja yksityisellä hyväntekeväisyydellä on merkittävä rooli. Tarkempaan kuvaukseen on valittu pieni yhteisö, Celebration, joka on Aittokosken mukaan kuin kiiltokuva, jossa valikoitu hyvätuloisten joukko viettää idyllistä elämää.

Tanska ja Suomi puolestaan edustavat valtioita, jossa on suhteellisen tasainen tulonjako, julkiset hyvinvointipalvelut ja korkea kansalaisten luottamus valtiota kohtaan. Francis Fukuyama (2014) onkin nimennyt kilvoittelun kohti hyvää yhteiskuntaa "pääsemisenä Tanskaan". Fukuyaman mukaan hän ei tarkoita mitään varsinaista maata, Tanskaa, vaan kuvitteellista yhteiskuntaa, symbolia vauraalle, demokraattiselle, turvalliselle ja hyvin hallitulle valtiolle. jossa korruptio on vähäistä. Kuten kaikissa esimerkkimaissa, myös Tanskassa ja Suomessa, Aittokoski tapaa ihmisiä ja kyselee, mitä se onnellisuus voisi olla. Tanskassa Aittokoskea kiinnostaa se, että ihmiset ottavat jätteiden kierrätyksen vakavasti. Suomessa puolestaan Pirkkala edustaa paikkakuntaa, joka on saanut mainintoja hyvistä palveluista ja suuria ongelmia ei näytä olevan.

Kaiken kaikkiaan hyvän yhteiskunnan kriteerit Pohjoismaissa ovat varsin selvät, ne takaavat kansalaisilleen tietyn turvan. Tämä puolestaan edellyttää laajaa voimavarojen jakamista ja sen hyväksyntää. Pohjoismaisissa hyvinvointivaltioissa vallitsee melko laaja kannatus voimavarojen jakamista suhteen; vähävaraiset tukevat jakamista ja keskiluokkakin katsoo voivansa tarvita tällaisia palveluja ja antaa näin kannatuksensa. Kirjan esimerkeistä Bhutan, Costa Rica ja Botswana eivät takaa kansalaisille korkealuokkaisia palveluja, mutta tietyn perusturvan ja sitoutumisen jakamiseen. Toisaalta tunnetaan myös resurssikirouksen käsite, eli se että esimerkiksi öljyn ja mineraalien tapaiset luonnonvarat tuovat rikkautta lähinnä omistajilleen, eivät laajemmin maan kansalaisille.

Onnelliset yhteiskunnat ovat siis toimivia ja tämä lisää osaltaan kansalaisten hyväksyntää. Toimivuus viittaa myös hyviin instituutioihin, joihin kansalaiset luottavat. Daron Acemoglu ja James Robinson väittävät teoksessaan Why Nations Fail (2013), että tavanomaisin syy valtioiden epäonnistumiseen on se, että instituutiot suosivat valtaapitävien rikastumista. Aittokosken tarkastelemat valtiot eroavat toisistaan poliittis-hallinnolliselta arkkitehtuuriltaan, mutta yleisesti onnelliset valtiot ovat hajautettuja, jolloin kansalaisilla on valtaa päättää paikallisista asioista. Paikallista autonomiaa mittaavassa LAI-indeksissä (Local autonomy index) sveitsiläiset, pohjoismaiset ja 
saksalaiset kunnat sijoittuvat kärkeen (Ladner ym. 2015). Eurostatin (2020) luottamusta mittaavalla asteikolla Tanska, Suomi ja Norja muodostavat kärkikolmikon. Pohjoismaiden kansalaiset siis luottavat poliittisiin instituutioihin keskimääräistä enemmän verrattuna muihin eurooppalaisiin valtioihin.

Kansalaisten luottamus siihen, että poliittinen päätöksenteko kohtelee kansalaisia tasapuolisesti, voi myös heiketä. Esimerkiksi Suomessa on vahvistunut terveyspalvelujen vakuutusperustainen käyttö, ja tämä voi osaltaan heikentää tukea julkisille terveyspalveluille. Aittokoski korostaa sitä, että hyvinvointivaltion ylläpito vaatii osallistumista kaikilta, jotka siihen suinkin kykenevät (s. 240). Tästä näkökulmasta Aittokoski katsoo verokeinottelun moraalinrapauttajaksi.

Eräs keskeinen ongelma onnellisilla valtioilla on sen määritys, keillä on oikeus nauttia onnesta. Aittokoski viittaakin kaikkien esimerkkivaltioiden kohdalla me ja muut -ilmiöön, josta räikein esimerkki on Yhdysvallat. Ilmiö on kuitenkin havaittavissa myös Bhutanissa muualta muuttaneiden kohdalla ja Botswanassa kohdentuen alkuperäisväestöön. Aittokoski ei nosta esille näitä kysymyksiä Suomen ja Tanskan kohdalla, vaikka erityisesti vuosien 2015-2016 jälkeen ksenofobia on voimistunut ja johtanut erilaisiin rajanvetoihin maassa asuvien oikeuksien suhteen. Euroopan väestön vanhetessa kysymys maahanmuutosta ja kulttuuristen arvojen muokkautumisesta vain voimistuvat tulevaisuudessa.

Kirjan päätösluvussa Aittokoski kertoo miettineensä mitä ottaisi kustakin matkakohteesta jos yrittäisi rakentaa ihanneyhteiskunnan, oman utopian (s. 251). Tämä muistuttaa Michael Mooren elokuvaa Where to invade next (2015), jossa haetaan Euroopasta Yhdysvaltoihin hyviä malleja muun muassa koulutuksessa (Suomi). Aittokoski ottaisi Bhutanista luontosuhteen, koska bhutanilaiset yrittävät tosissaan pitää ihmisen toiminnan sellaisissa rajoissa, että henkeäsalpaava luonto säilyy ehjänä tuleville sukupolville. Yhdysvalloista hän ottaisi dynaamisuuden, tekemisen meiningin ja mahdottomuuksiin uskomisen. Costa Ricasta hän ottaisi armeijattomuuden sekä onnellisuuskäsityksen, jota arvioidaan muillakin kuin talousmittareilla. Botswanasta Aittokoski ottaisi perinteisen kgotla-instituution, siis heimoneuvostot, jotka suomalaisiin olosuhteisiin sovellettuina tarkoittaisivat kaupunginosien ja maaseutupitäjien kansankokouksia, jotka olisivat niin olennainen osa tapakulttuuria, että kansalaiset pitäisivät niihin osallistumista tärkeänä. Tanskalaisilta Aittokoski ottaisi rennon itsevarmuuden ja sosiaaliset taidot. Suomesta Aittokoski ottaisi hyvinvointivaltion rakenteet, etenkin ne, jotka yrittävät taata kaikille lapsille mahdollisuuden kasvaa ja kehittää itseään.

Kirjan lopuksi Aittokoski listaa kirjallisuutta, mikäli lukija haluaa perehtyä tarkemmin Moreen, Platoniin tai muutamiin maakohtaisiin teoksiin. Kaiken kaikkiaan Aittokosken teos toimii hyvänä johdantona onnellista yhteiskuntaa käsittelevään keskusteluun. Se voi myös toimia kannustimena tehdä vertailevaa tutkimusta onnellisista ja toimivista yhteiskunnista sekä erilaisista prosesseista, jotka voivat johtaa kohti onnellisuutta. Teos myös osoittaa, ettei täydellistä valtiota ei ole, vaan kyse on sen tavoittelusta. Näyttää kuitenkin siltä, että globaalisti ollaan menossa parempaan suuntaan. Kaikkein köyhimpien osuus on vähentynyt ja vastoin yleistä uskomusta suurin osa maailman lapsista käy koulua (ks. Rosling ym. 2018). 


\section{LÄHTEET}

Acemoglu, Daron ja Robinson, James A. 2013. Why Nations Fail. The Origins of Power, Prosperity and Poverty. Lontoo: Profile books.

Aittokoski, Heikki. 2013. Narrien laiva. Matka pieleen menneessä maailmassa. Helsinki: HS-kirjat. Aittokoski Heikki. 2016. Kuoleman tanssi. Askeleita nationalismin Euroopassa. Helsinki: HS-kirjat. Eurostat. 2020. Quality of life indicators - governance and basic rights. https://ec.europa.eu/eurostat/statistics-explained/index.php?title=Quality_of_life_indicators_-_governance_and_basic_ rights\&oldid=504055\#Trust_in_the_political_and_legal_systems. Viitattu 8.3.2021.

Fukuyama, Francis. 2011. Political Order and Political Decay. Lontoo: Profile books.

GNH Centre. 2020. What is GNH. http://www.gnhcentrebhutan.org/what-is-gnh/. Viitattu 8.3.2021.

Ladner, Andreas, Keuffer, Nicolas ja Baldersheim, Harald. 2015. Local Autonomy Index for European countries (1990-2014). Release 1.0. Brysseli: Euroopan komissio.

More, Thomas. 1971. Utopia. Helsinki: WSOY.

Rosling, Hans, Rosling, Ola ja Rosling Rönnlund, Anna. 2018. Faktojen maailma. Asiat ovat paremmin kuin luulet. Helsinki: Otava.

Rotterdamilainen, Erasmus. 2010. Tyhmyyden ylistys. Hämeenlinna: Karisto.

Strindberg, August. 1912. Onnellisten saari. Kaksi kertomusta kokoelmasta "Svenska öden och äfventyr. Helsinki: Otava.

Yhdistyneet kansakunnat. 2020. World Happiness Report 2020. https://worldhappiness.report/. Viitattu 8.3.2021

\section{KIRJOITTAJATIEDOT}

\section{PEKKA KETTUNEN}

Dosentti, erikoistutkija

Siirtolaisuusinstituutti, Turku

pekka.kettunen@utu.fi 